\title{
Comprehensive condition assessment program on the fire damaged structure - a project case in Singapore
}

\author{
Gunawan Budi Wijaya ${ }^{1, *}$ \\ ${ }^{1}$ Petra Christian University, Department of Civil Engineering, Indonesia
}

\begin{abstract}
A fire damaged structure at the eastern part of Singapore was assessed. Some concrete spalling exposing corroded steel reinforcements were noted on the post tensioned concrete beam and reinforced concrete slab, raising a concern about the structural integrity of the overall floor. A comprehensive condition assessment was performed on the affected structural elements to determine the extent of the damage, which included some on-site destructive and non-destructive tests as well as some laboratory testing on the collected concrete and steel samples. Testing data revealed that the concrete was still in consistently good condition with the average residual compressive strength of $36.51 \mathrm{MPa}$. Petrographic examinations suggested that the top $5 \mathrm{~mm}$ of the concrete surface might be exposed to a temperature not more than $450^{\circ} \mathrm{C}$. The steel reinforcement and post tension strands were found to be still in good condition as well. The findings of this assessment will then be used for further structural assessment to determine the most effective structural rehabilitation program.
\end{abstract}

\section{Introduction}

A fire incident occurred at a construction site in the Eastern Part of Singapore. The area of the fire incident was reported to be confined within a relatively small area of approximately $24 \mathrm{~m} \times 9.5 \mathrm{~m}$. The fire started on a few bundles of carpet (stacked up to approximate $1.3 \mathrm{~m}$ from ground level) which was stored in a room on the $3^{\text {rd }}$ storey of the building. The actual cause of the fire was unknown and it was suspected that the carpet caught fire from some unknown source, possibly a cigarette butt. The fire was estimated to last for at least 1 hour before it was extinguished.

Some concrete spalling exposing corroded steel reinforcements were noted on the roof level post tensioned beam and reinforced concrete slab as shown in Figure 1. However, no sign of concrete defect was found on the $3^{\text {rd }}$ storey beam and slab where the fire occurred. The objective of the works was to evaluate the condition of the affected structure and the residual material mechanical properties.

To determine the most effective structural rehabilitation program, which includes structural repair and strengthening works, further to this condition assessment, a complete structural assessment was performed.

\footnotetext{
* Corresponding author: gunawanbw@petra.ac.id
} 


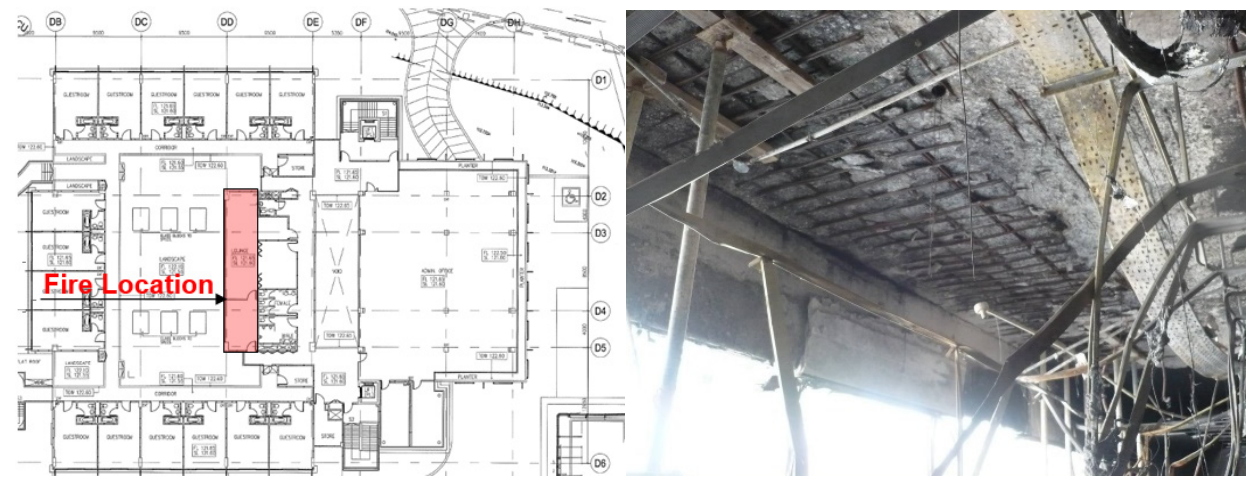

Fig. 1. Fire location and concrete spalling on roof level beam and slab.

\section{Literature review}

When exposed to high temperatures, such as in the case of a fire, the concrete surface will become porous with lots of void and micro cracks. Some portion of the concrete may have shallow delamination, and some may even spall off. Porous concrete will reduce its compressive strength and increase the risk of rebar corrosion [1-4].

The extent of concrete damage, such as carbonation depth, the existence of void and micro cracks, and estimation of concrete temperature during a fire can be examined using petrographic examination on the concrete core sample. Petrographic examination was performed in accordance to ASTM C856-04 on a ground section using a stereo microscope and on a thin section with a polarizing and fluorescent microscope (PFM), under transmitted and reflected light. Through an examination of the ground section, the assessment was made on the homogeneity of the concrete, compaction and types and distribution of large particles. Under transmitted light on the examination of a thin section, various components (type of cement and aggregates), air voids content, compaction pores and damage phenomenon in the sample were identified. Under reflected light, the fluorescent microscopy made it possible to study the homogeneity of the mix and the cement paste, capillary porosity, micro cracks and other defects in the sample [5-7].

The residual concrete compressive strength might be the most important thing to be assessed to ensure the affected structures still have the required capacity to take the load. The compressive test was conducted on the extracted core samples [8].

Although the concrete surface may look to be in a good condition, with no crack and spalling, some internal separation (delamination) may occur, which is quite dangerous if not properly assessed. Structural repairs are required for this area to prevent concrete spalling in the future. Acoustic impact testing was used to detect the concrete area with shallow delamination. Using the principle of emission of elastic sound waves, the impacted surfaces exhibit either a sharp metallic ring or a dull hollow sound representing "sound" and "unsound" concrete conditions, respectively [9].

It would be difficult to assess the extent of damage the fire caused to the structure unless a lot of samples are taken. To minimize the number of samples, a material uniformity test is required. This can be done using the Rebound Hammer test on the accessible concrete surface. Once the test showed that the readings of the material were not uniform, more samples would be required [10].

After the fire reached a certain temperature, the steel mechanical properties, including its tensile strength, ductility, and hardness will change [11]. The tensile strength test is required to determine the residual strength of the steel rebar to ensure that it has the required strength as per design requirement. Steel bend test is one method to qualitatively evaluate ductility. It 
is done by bending the steel sample to a $45^{\circ}$ angle and then heating it up to $100^{\circ} \mathrm{C}$ for at least 30 minutes. After it cools down the specimen is re-straightened to at least a $23^{\circ}$ angle and it should not show any damage [12]. Vickers hardness test is used to evaluate the steel rebar hardness. A constant force of $10 \mathrm{~kg}$ is often used to obtain the Vickers Hardness Value (VH10), which can be indicatively correlated to give an estimation to its yield strength [13, $14]$.

\section{Condition assessment}

Condition assessment works were performed in accordance to ACI 364.1R-07 on the affected PT Beam and RC Slab on the roof and $3^{\text {rd }}$ level, which consisted of Field Assessment and Laboratory Test [15].

\subsection{Field assessment}

Field assessment included Visual Inspection, Acoustic Impact testing, Ferroscan Pachometer survey, Rebound hammer testing and collection of concrete core and steel rebar samples. The locations of the field assessment are shown in Figure 2.

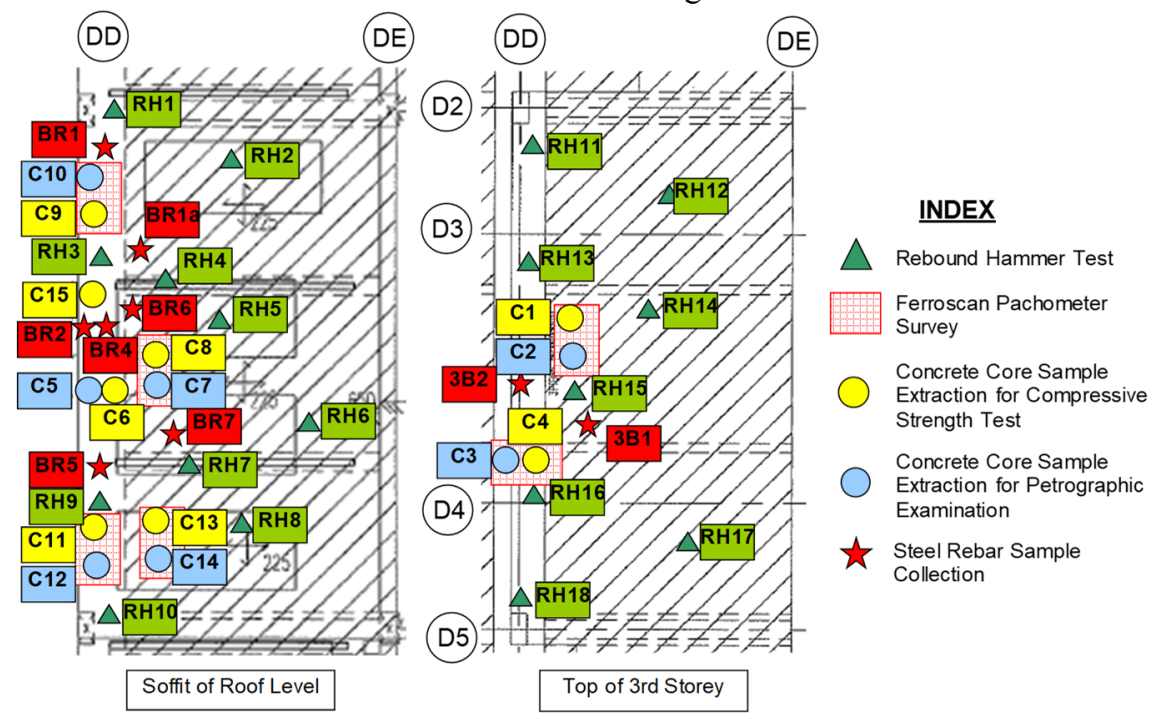

Fig. 2. Location of the field assessment.

\subsubsection{Visual inspection}

Accessible areas of the concrete structure were visually examined. Some concrete spalling exposing corroded steel reinforcements were noted on the roof storey beam and slab soffit. No sign of concrete defect was found on the $3^{\text {rd }}$ storey beam and slab where the fire occurred. No damage was noted on the PT Tendon ducts, even at the most severely spalled concrete.

\subsubsection{Acoustic impact testing}

Generally, unsound (i.e., delaminated) areas were in the immediate proximity of cracks in the beams. No concrete delamination was noted outside the spalled concrete area. 


\subsubsection{Rebound hammer testing}

This method is not intended as an alternative for strength determination of concrete, but rather the scale number values provide qualitative comparisons between similar concrete materials. Typically, for each location, a series of 10 readings are performed approximately $25 \mathrm{~mm}$ apart with test results recorded and tabulated. Eighteen (18) locations were tested with Rebound Hammer testing. A total of 180 readings were taken. Interpolating concrete strengths derived from Rebound Hammer manufacturer Data Charts, revealed a mean interpretative compressive strength of $30-50 \mathrm{~N} / \mathrm{mm}^{2}$. A summary of Rebound Hammer readings is presented in Table 1.

Table 1. Summary of rebound hammer test results.

\begin{tabular}{|c|c|c|c|c|c|}
\hline \multirow{2}{*}{ No } & \multirow{2}{*}{ Location } & \multicolumn{3}{|c|}{ Measurement } & \multirow{2}{*}{$\begin{array}{l}\text { Interpretive } \\
\mathbf{f}_{\mathrm{cu}}\left(\mathrm{N} / \mathbf{m m}^{2}\right)\end{array}$} \\
\hline & & Low & High & Ave & \\
\hline 1 & Roof level beam soffit & 39 & 48 & 44 & 40 \\
\hline 2 & Roof level slab soffit & 42 & 47 & 45 & 40 \\
\hline 3 & Roof level beam soffit & 40 & 47 & 44 & 40 \\
\hline 4 & Roof level secondary beam soffit & 39 & 43 & 41 & 40 \\
\hline 5 & Roof level slab soffit & 39 & 48 & 44 & 40 \\
\hline 6 & Roof level slab soffit & 40 & 49 & 45 & 40 \\
\hline 7 & Roof level secondary beam soffit & 38 & 42 & 40 & 40 \\
\hline 8 & Roof level slab soffit & 37 & 43 & 40 & 40 \\
\hline 9 & Roof level beam soffit & 35 & 45 & 40 & 40 \\
\hline 10 & Roof level beam soffit & 36 & 48 & 42 & 40 \\
\hline 11 & $3^{\text {rd }}$ level top beam & 28 & 32 & 30 & 30 \\
\hline 12 & $3^{\text {rd }}$ level top slab & 32 & 36 & 34 & 40 \\
\hline 13 & $3^{\text {rd }}$ level top beam & 36 & 40 & 38 & 40 \\
\hline 14 & $3^{\text {rd }}$ level top slab & 32 & 36 & 34 & 40 \\
\hline 15 & $3^{\text {rd }}$ level top slab & 31 & 35 & 33 & 30 \\
\hline 16 & $3^{\text {rd }}$ level top beam & 30 & 38 & 34 & 40 \\
\hline 17 & $3^{\text {rd }}$ level top slab & 32 & 38 & 35 & 40 \\
\hline 18 & $3^{\text {rd }}$ level top beam & 38 & 42 & 40 & 50 \\
\hline
\end{tabular}

\subsubsection{Ferroscan pachometer survey}

The ferroscan pachometer surveys were performed to estimate the core sample locations. No scans were performed on the concrete surface with exposed rebars as the core sample location can be visibly determined.

\subsubsection{Concrete core and steel rebar sample extraction}

Fifteen (15) concrete core specimens were collected using wet rotary diamond core drilling techniques at selected locations. Concrete core samples were visually examined and photographed prior to concrete laboratory testing. Concrete core holes were patched with shrinkage-compensating repair mortar subsequent to sample collection.

A total of nine (9) steel rebar samples were collected on site. Seven (7) samples were collected from the roof level which is grade 460 rebar, and two (2) samples (3B1 and 3B2) were collected from the $3^{\text {rd }}$ storey level which is A6 BRC. The collected steel samples were sent to the accredited laboratory for further laboratory tests 


\subsection{Laboratory test}

Laboratory Test on the collected concrete core samples included a concrete compressive test and petrographic examination, while tensile strength, bending, and hardness tests were performed on the collected steel rebar sample.

\subsubsection{Concrete compressive strength test}

Eight (8) numbers of extracted core samples were tested to determine the laboratory compressive strength. The core samples were prepared by the laboratory such that it reflected the homogeneity of the sample. The summary of the test result, which ranges from 30.00 to $39.00 \mathrm{~N} / \mathrm{mm}^{2}$, is shown in Table 2 .

Table 2. Summary of compression strength test result.

\begin{tabular}{|c|c|c|}
\hline $\begin{array}{l}\text { Core sample } \\
\text { reference }\end{array}$ & Location & $\begin{array}{l}\text { Estimated in situ cube } \\
\text { strength } \mathbf{f}_{\mathrm{cu}}\left(\mathbf{N} / \mathbf{m m}^{2}\right)\end{array}$ \\
\hline $\mathrm{C} 1$ & $3^{\text {rd }}$ Floor Top Slab & 33.00 \\
\hline $\mathrm{C} 4$ & $3^{\text {rd }}$ Floor Top Slab & 32.50 \\
\hline C6 & Roof Level Beam Soffit & 38.50 \\
\hline $\mathrm{C} 8$ & Roof Level Slab Soffit & 30.00 \\
\hline C9 & Roof Level Beam Soffit & 36.50 \\
\hline $\mathrm{C} 11$ & Roof Level Beam Soffit & 35.50 \\
\hline $\mathrm{C} 13$ & Roof Level Slab Soffit & 39.00 \\
\hline $\mathrm{C} 15$ & Roof Level Beam Soffit & 32.50 \\
\hline
\end{tabular}

\subsubsection{Petrographic examination}

Petrographic examinations were performed on seven (7) submitted core samples to determine the extent of the concrete damage. All samples were analyzed starting from the sample surface exposed to the fire. Carbonation was noted within the $5 \mathrm{~mm}$ depth. Some micro cracks were noted on the cement paste (see Figure 3). Some of these were not fire-induced cracks which occurred before the fire. The summary of the petrographic examination is shown in Table 3 .

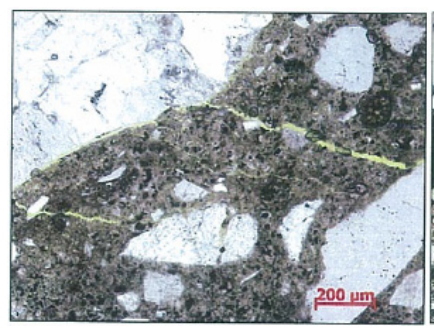

(a) Under plane polarized light

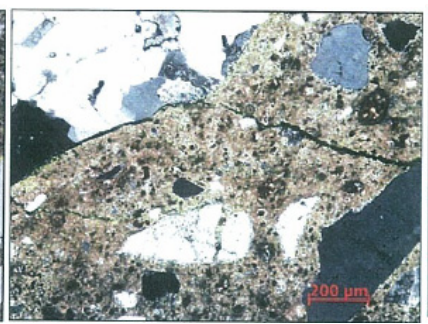

(b) Under cross polarized light

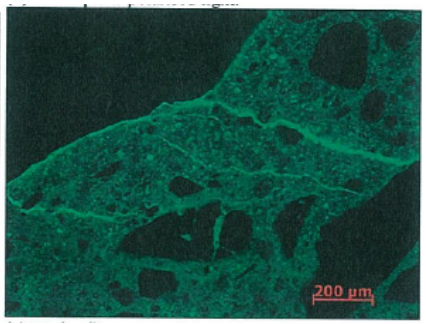

(c) Under fluorescent light

Fig. 3. Petrographic examination of core sample $\mathrm{C} 7$ showing sub-parallel micro cracks near the exposed surface. 
Table 3. Summary of petrographic examination results.

\begin{tabular}{|c|c|c|c|c|}
\hline $\begin{array}{c}\text { Core } \\
\text { sample } \\
\text { reference }\end{array}$ & Location & $\begin{array}{c}\text { Carbonation } \\
\text { depth }\end{array}$ & Cement paste condition & $\begin{array}{l}\text { Estimated } \\
\text { exposed } \\
\text { temperature }\end{array}$ \\
\hline $\mathrm{C} 2$ & $\begin{array}{l}3^{\text {rd }} \text { Floor } \\
\text { Top Slab }\end{array}$ & $4 \mathrm{~mm}$ & $\begin{array}{l}\text { - Very small amount of micro cracks on } \\
\text { cement paste were noted. } \\
\text { - No Aggregate-cement paste debonding } \\
\text { was noted }\end{array}$ & $<300^{\circ} \mathrm{C}$ \\
\hline $\mathrm{C} 3$ & $\begin{array}{c}3^{\text {rd }} \text { Floor } \\
\text { Top Beam }\end{array}$ & $4 \mathrm{~mm}$ & $\begin{array}{l}\text { - Hardened Crack with aggregate-cement } \\
\text { paste debonding was noted at within } 3 \mathrm{~mm} \\
\text { from the exposed surface } \\
\text { - No fire-induced micro cracks were } \\
\text { noted }\end{array}$ & $<300^{\circ} \mathrm{C}$ \\
\hline $\mathrm{C} 5$ & $\begin{array}{l}\text { Roof Level } \\
\text { Beam Soffit }\end{array}$ & $0.5 \mathrm{~mm}$ & $\begin{array}{l}\text { - Hardened Crack with aggregate-cement } \\
\text { paste debonding was noted at within } 4 \mathrm{~mm} \\
\text { from the exposed surface } \\
\text { - No fire-induced micro cracks were } \\
\text { noted }\end{array}$ & $<450^{\circ} \mathrm{C}$ \\
\hline $\mathrm{C} 7$ & $\begin{array}{l}\text { Roof Level } \\
\text { Slab Soffit }\end{array}$ & $2 \mathrm{~mm}$ & $\begin{array}{l}\text { - Hardened Crack with aggregate-cement } \\
\text { paste debonding was noted at within } \\
20 \mathrm{~mm} \text { from the exposed surface } \\
\text { - No fire-induced micro cracks were } \\
\text { noted }\end{array}$ & $<450^{\circ} \mathrm{C}$ \\
\hline $\mathrm{C} 10$ & $\begin{array}{l}\text { Roof Level } \\
\text { Beam Soffit }\end{array}$ & $1.5 \mathrm{~mm}$ & $\begin{array}{l}\text { - Hardened Crack with aggregate-cement } \\
\text { paste debonding was noted at within } \\
20 \mathrm{~mm} \text { from the exposed surface } \\
\text { - No fire-induced micro cracks were } \\
\text { noted }\end{array}$ & $<450^{\circ} \mathrm{C}$ \\
\hline $\mathrm{C} 12$ & $\begin{array}{l}\text { Roof Level } \\
\text { Slab Soffit }\end{array}$ & $4 \mathrm{~mm}$ & $\begin{array}{l}\text { - Hardened Crack with aggregate-cement } \\
\text { paste debonding was noted at within } \\
1.5 \mathrm{~mm} \text { from the exposed surface } \\
\text { - No fire-induced micro cracks were } \\
\text { noted }\end{array}$ & $<450^{\circ} \mathrm{C}$ \\
\hline $\mathrm{C} 14$ & $\begin{array}{l}\text { Roof Level } \\
\text { Beam Soffit }\end{array}$ & $3 \mathrm{~mm}$ & $\begin{array}{l}\text { - Hardened Crack with aggregate-cement } \\
\text { paste debonding was noted at within } \\
1.5 \mathrm{~mm} \text { from the exposed surface } \\
\text { - No fire-induced micro cracks were } \\
\text { noted }\end{array}$ & $<450^{\circ} \mathrm{C}$ \\
\hline
\end{tabular}

\subsubsection{Steel rebar test}

The tensile test results showed that the yield strength ranged from 573.10 to $670.50 \mathrm{~N} / \mathrm{mm}^{2}$ which was more than the requirement specified in BS 4449:1997 of $460 \mathrm{~N} / \mathrm{mm}^{2}$. The bending test showed a satisfactory result for all the rebar samples. The Vickers Hardness Test showed an HV10 value range from 175 to 300 , which could be correlated to estimate the tensile strength of 590 to $960 \mathrm{~N} / \mathrm{mm}^{2}$. The summary of the steel rebar test is shown in Table 4.

\section{Analysis}

\subsection{Concrete material properties}

Compressive strength results indicated that concrete strength ranged from 30.00 to 39.00 $\mathrm{N} / \mathrm{mm}^{2}$. The average laboratory compressive strength tested for eight (8) of the concrete cores 
extracted was $34.69 \mathrm{~N} / \mathrm{mm}^{2}$. BS1881 Part 120 allows extracted concrete core specimens subjected to laboratory compression testing to represent $95 \%$ of the design compressive strength due to the destructive nature of the core extraction process. Thus, the average residual concrete compressive strength on the site shall be $36.51 \mathrm{~N} / \mathrm{mm}^{2}$, which was slightly higher than the original design compressive strength of $35 \mathrm{~N} / \mathrm{mm}^{2}$.

Table 4. Summary of steel tensile, bending, and hardness test result.

\begin{tabular}{|c|c|c|c|c|}
\hline $\begin{array}{c}\text { Sample } \\
\text { reference }\end{array}$ & Location & $\begin{array}{c}\text { Yield } \\
\text { strength } \\
\left(\mathbf{N} / \mathbf{m m}^{2}\right)\end{array}$ & Bending test & HV10 \\
\hline BR1 & Roof Level Beam Soffit & 635.00 & Satisfactory & $188-230$ \\
\hline BR1a & Roof Level Slab Soffit & 581.80 & Satisfactory & $188-237$ \\
\hline BR2 & Roof Level Beam Soffit & 623.70 & Satisfactory & $192-237$ \\
\hline BR4 & Roof Level Beam Soffit & 670.50 & Satisfactory & $192-300$ \\
\hline BR5 & Roof Level Beam Soffit & 650.70 & Satisfactory & $196-242$ \\
\hline BR6 & Roof Level Slab Soffit & 608.50 & Satisfactory & $194-219$ \\
\hline BR7 & Roof Level Slab Soffit & 573.10 & Satisfactory & $175-233$ \\
\hline 3B1 & $3^{\text {rd }}$ Floor Top Slab & 530.70 & Satisfactory & $208-227$ \\
\hline 3B2 & $3^{\text {rd }}$ Floor Top Beam & 570.70 & Satisfactory & $215-218$ \\
\hline
\end{tabular}

Rebound Hammer conducted on the concrete structure revealed relatively consistent concrete material properties. Testing data revealed that the concrete could be considered in a general "good" condition. No concrete delamination was noted outside the concrete spalled area as confirmed by the acoustic impact testing. The location of the "bad" concrete required to be repaired is determined as shown in Figure 4.

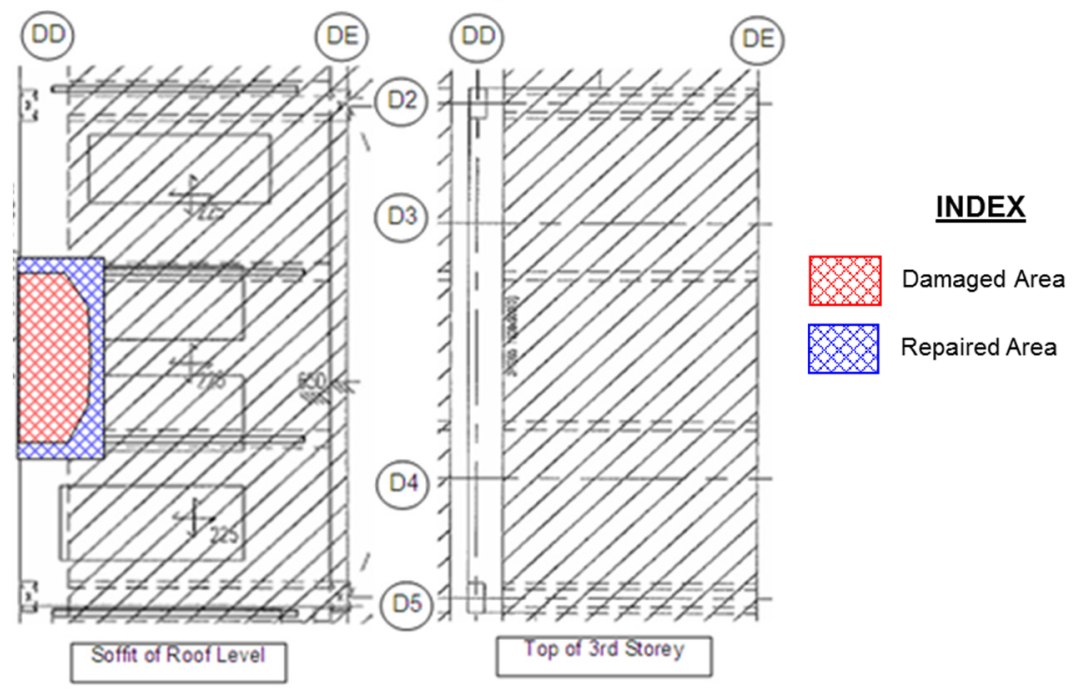

Fig. 4. Schematic location of the core sample depth for the compressive strength test.

Petrographic examination showed that all tested core samples had some carbonation that occurred at a depth of $5 \mathrm{~mm}$ below the exposed surface. At the location where concrete spalled exposing steel rebar, the exposed surface was deeper than the steel rebar depth. Hence, concrete material carbonation might be a significant contributor to the steel rebar corrosion in the future. However, in the location where there was no concrete spalling, the $5 \mathrm{~mm}$ deep carbonation was well within the concrete cover, thus carbonation would not have a significant impact on rebar corrosion. 
Some micro cracks were noted inside the cement paste within $20 \mathrm{~mm}$ from the exposed surface. Some of these micro cracks were existing cracks which occurred before the fire whereas some were fire-induced. Some aggregate-cement paste debonding was observed on the existing micro cracks within $20 \mathrm{~mm}$ from the exposed surface. However, no cracks were observed on the aggregates. The concrete at the depth of more than $20 \mathrm{~mm}$ was considered to be in good condition as no signs of distress were observed.

Petrographic examination suggested that the top $5 \mathrm{~mm}$ of the concrete surface might be exposed to a temperature not more than $450^{\circ} \mathrm{C}$. The remaining depth of the concrete was strongly believed to be exposed to a temperature of less than $300^{\circ} \mathrm{C}$.

\subsection{Steel material properties}

All three tests (tensile, bending, and hardness) on the steel samples showed that the steel rebars were still in good condition with no significant material degradations caused by the fire incident. All post tension strands were encased inside fully grouted corrugated steel ducts. In order for the fire to damage the strands, the heat needed to go through the $70 \mathrm{~mm}$ thick concrete cover, steel duct, and about $30 \mathrm{~mm}$-thick grout. After the fire incident, no tendons were exposed even at the most severely spalled concrete. This showed that the strands were still in good condition. Thus, it could be concluded that the steel rebars and PT strands were considered to be structurally able to perform as designed.

\section{Conclusion}

A comprehensive condition assessment is a very important work to determine the extent of structural damage and the residual material mechanical properties. The findings of this assessment were used for the structural assessment work to determine the residual structural capacity of the affected structural elements. The effective structural rehabilitations, which includes structural repair and strengthening works, were done based on the findings of both condition and structural assessment works, respectively.

The Author would like to give acknowledgment to VSL Singapore Pte. Ltd. for the overall works, which included the condition and structural assessment, as well as the structural rehabilitation works.

\section{References}

1. T. Ha, J. Ko, S. Lee, S. Kim, J. Jung, D. Kim, Appl Sci, 6 (2016)

2. O. Arioz, Fire Safety Journal 42, 516-522 (2007)

3. Q. Ma, R Guo, Z. Zhao, Z. Lin, K. He, Const. \& Build. Mat. 93, 371-383 (2015)

4. B. Georgali, P.E. Tsakiridis, Cement \& Concrete Composites 27, 255-259 (2005)

5. ASTM C856, ASTM International, Standard Practice for Petrographic Examination of Hardened Concrete (2004)

6. J. P. Ingham, Material Characterization 60, 700-709 (2009)

7. E. Annerel, L. Taerwe, Cement and Concrete Research 39, 1239-1249 (2009)

8. BS 1881: Part 120, British Standard Institution, Method for determination of the compressive strength of concrete cores (1983)

9. ASTM D4580, ASTM International, Practice for measuring delaminations in concrete bridge decks by sounding (2002) 
10. ASTM C805, ASTM International, Standard test method for rebound number of hardened concretes, (2002)

11. A.Y. Elghazouli, K.A. Cashell, B.A. Izzuddin, Fire Safety Journal, 44, 909-919 (2009)

12. BS 4449, British Standard Institution, Specification for carbon steel bars for the reinforcement of concrete (1997)

13. ASTM E92, ASTM International, Standard test method for vickers hardness of metallic materials, (2003)

14. ASTM A370, ASTM International, Standard methods and definitions for mechanical testing of steel products, (1977)

15. ACI 364.1R-07, ACI Committee 364, Guide for evaluation of concrete structures before rehabilitation (2007) 